\title{
MRI よりみた成長腰部椎間板変性の検討
}

\section{（椎体終板前障害と䯣核変性について）}

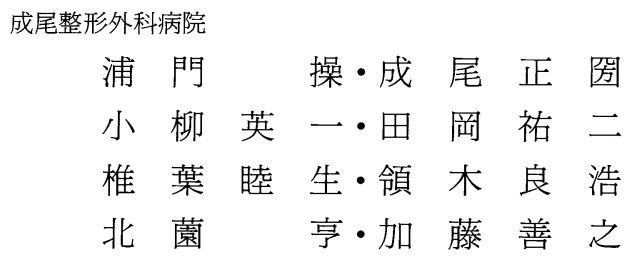

\section{Evaluation of Lumbar Disc Lesions in Teen-agers using Magnetic Resonance Imaging}

- A correlative Study between Peridiscal Singnal Intensity and Nuclear Signal intensity in 500 Discs-

by

Misao Urakado, Masakuni Naruo, Eiichi Koyanagi, Yuuji Taoka, Mutuo Shiiba, Yoshihiro Ryouki, Tooru Kitazono and Yoshiyuki Kato

Naruo Orthopedic Hospital (Kumamoto City)

\begin{abstract}
The peridiscal and nuclear (uncleus pulposus and inner layer of annulus fibrosus) signal intensities in 500 discs of teen-age patients were compared with common degenerative lumbar disc disease. Images were taken with a $7 \mathrm{~mm}$ slice thickness and $\mathrm{T}_{2}$ wighted (TE $80 \sim 90 \mathrm{mS}$, TR 2000 $\sim 2200 \mathrm{mS}$ ) midsagittal imaging. Clear correlation between these intensities was found. The signal intensity primarily decreased in the peridiscal tissues and secondarily decreased in the nucleus pulposus and inner layer of annulus fibrosus. These findings suggest that peridiscal disorders cause degenerative changes of the nucleus pulposus. Additionally, in the early degenerative stage of the teen-age lumbar disc, a decrease of nuclear signal intensity insicated that degenerative changes originated from the anterior portion and extended posteriorly.
\end{abstract}

Key words : Magnetic resonance imaging (磁気共鳴画像), Peridiscal signal intensity (終板信号強 度), Nuclear signal intensity (髄核信号強度), Disc degeneration (椎間板変性), Teenagers（弱年）

はじめに

MRIに抢ける椎体終板前障害と椎間板変性との関 連についてはいくつかの報告 ${ }^{11,18)}$ があるが, 弱年者の みの終板前信号強度と髄核信号強度との関連性につい ての報告 ${ }^{15,199}$ は少ない。

椎間板変性の始まりを組織学的に脊索細胞の消失し はじめる 14 才以降6あるいは消失する 20 才代とする
報告3)があるが，今回変性初期の変化が観察される 10 代を対象とし, 椎体終板前変化と䯣核変性との関連性 について MR 画像により検討した。

\section{対象と方法}

MR 画像上髄核に輝度低下の認められた 10 才代の 腰椎椎間板 100 例 500 椎間板を対象とした (図 1 ). 隅 角解離やSchmorl 結節，外傷例は除外した。MR 装置 


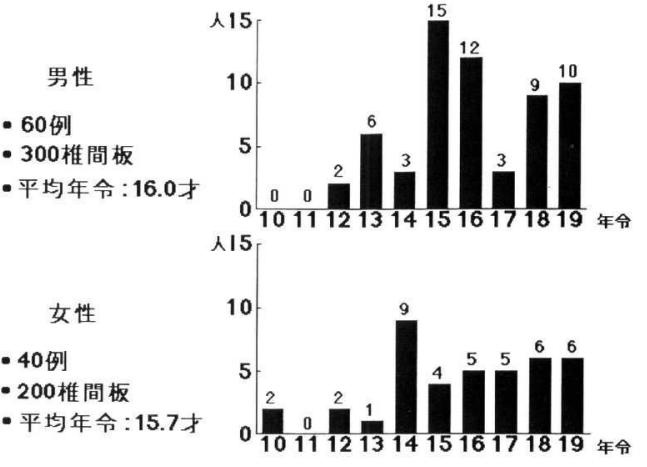

図 1 調查対象者年令別症例数

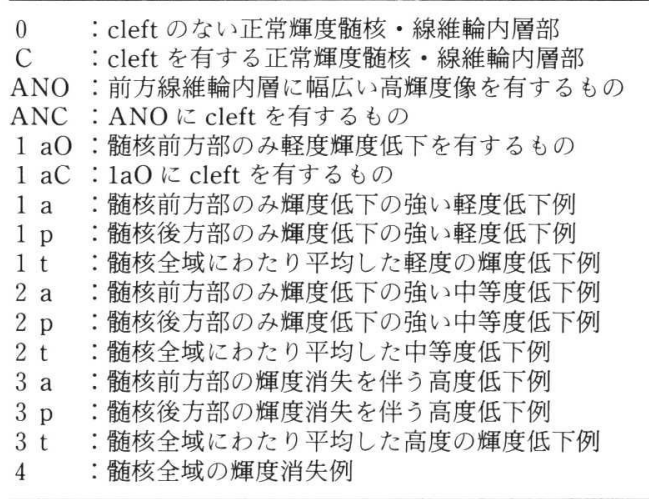

図 2 髄核・線維輪内層部の MRI 輝度分類

は島津制作所製 SMP50X, 磁場強度 0.5 Tesla の超電 導装置を用い, 撮象条件は椎間板の水分が描出されや すい TE $80 \sim 90 \mathrm{mS}$, MR $2000 \sim 2200 \mathrm{mS}$ と し, $\mathrm{T}_{2}$ midisagittal 画像で検討した。

髄核及び線維輪内層の信号強度 nuclear signal intensity，NSの分類は信号強度の低下を全く認めな いものを 0 度, 軽度低下するものを 1 度, 中等度低下 するものを 2 度，高度低下するものを 3 度，消失する ものを 4 度とした. 組織学的には intranuclear cleft を周囲から線維化が層状に始まる超早期の変性である とする報告があるが, 臨床的には無症状であり, Aguila ${ }^{11}$ は Normal anatomical structure, Maravilla ${ }^{11)}$ は normal intradiscal cleft と報告してお り cleft を伴うものは正常とした。 そこで 0 度を cleft

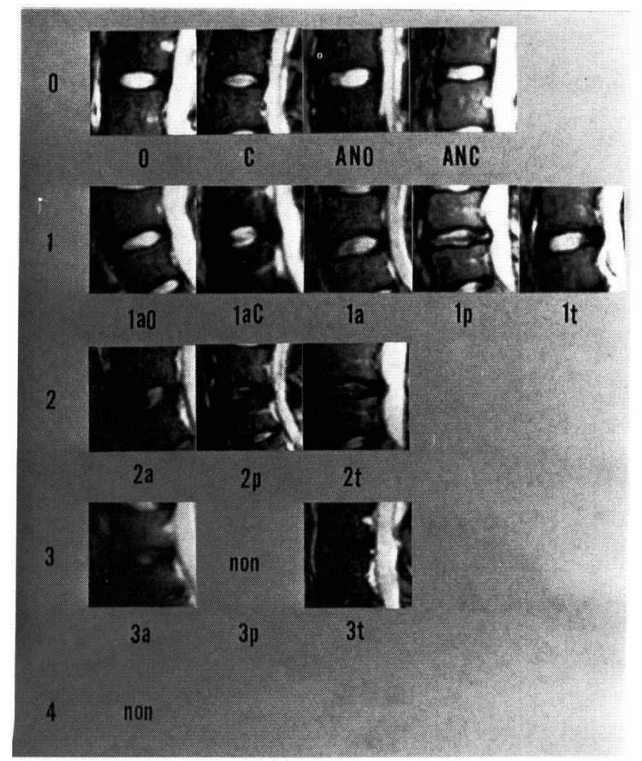

図 3 NS の分類画像（図 2 参照）

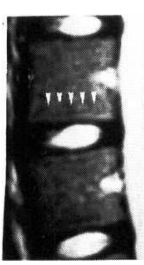

0

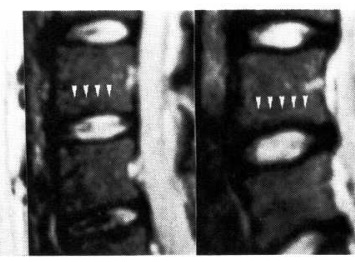

II

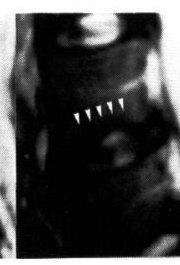

III
図４ＰDS の分類画像（本文参照）

を伴わない $\mathrm{O}$ 型と伴う $\mathrm{C}$ 型に分け,さらに特に前方線 維輪内層部に幅広く高い信号強度を有するものを ANO, ANC 髄核前方部のみ信号低下を認めるものを $\mathrm{laO}, 1 \mathrm{aC}$ とた(図 2 )。また 1 度・2 度・3 度をより 強く信号の低下する部位により前方型 $\mathrm{a}$, 後方型 $\mathrm{p}$, 全 域型 $\mathrm{t}$ に分類した (図 3 ). 終板の信号強度 peridiscal signal intensity, PDS はその低下度より0 度: 正常 (椎体と同程度の輝度を有するもの), I 度 : 辺縁部の 不整・不明瞭化・もうろう化を有するもの, II度：明 らかな軽度・中等度の輝度低下を有するもの, III度： 高度輝度低下又はほぼ消失,の 4 型に分類した(図 4 ).

結

果

500 椎間板中正常髄核は $68 \%$ で, 前方部のみ信号低 


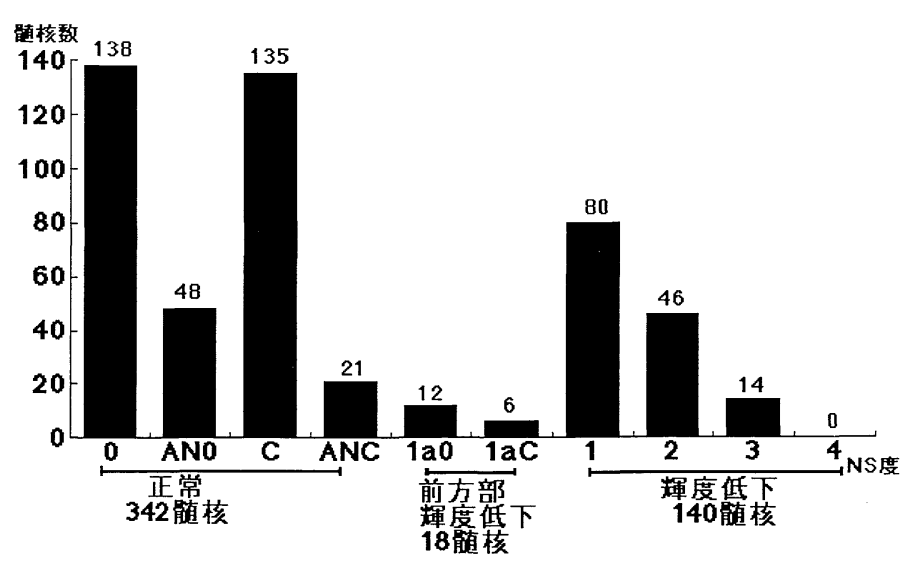

図 5 NS の輝度別頻度

\section{骭核数}

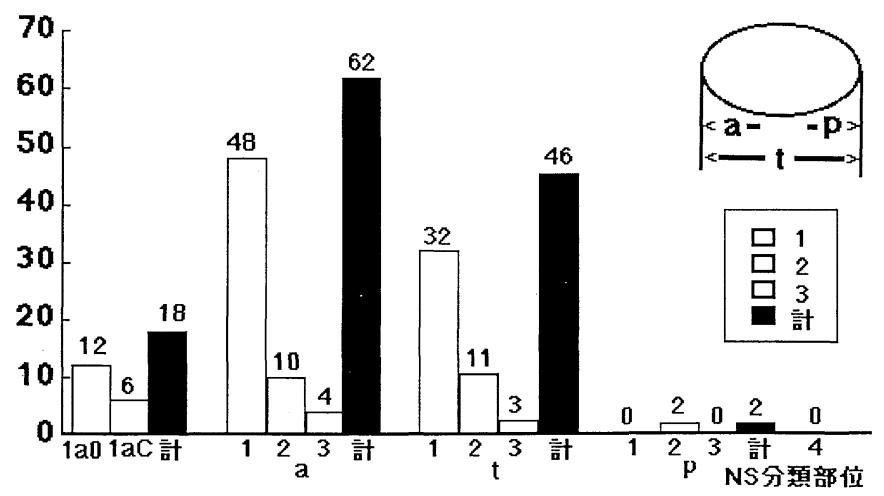

図 6 NS 低下髄核の部位別頻度

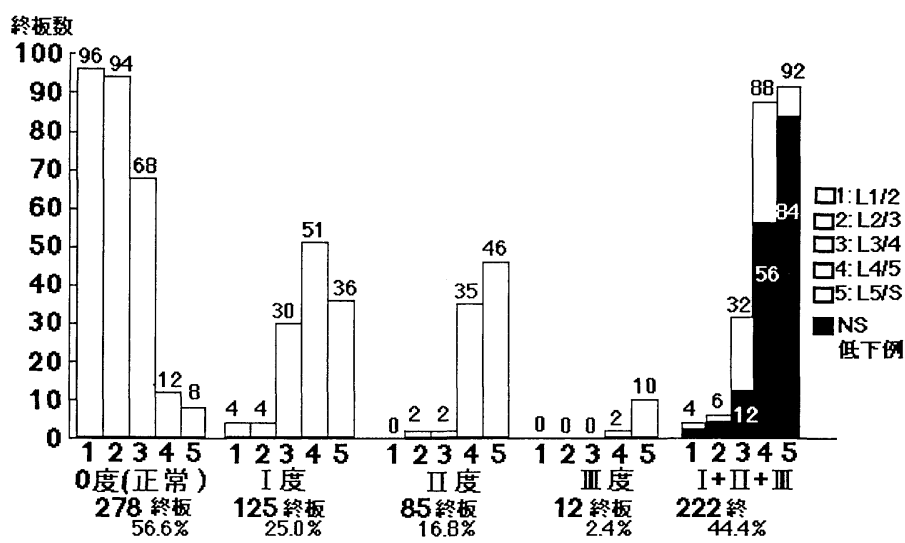

図 7 PDS 輝度別・レベル別頻度 


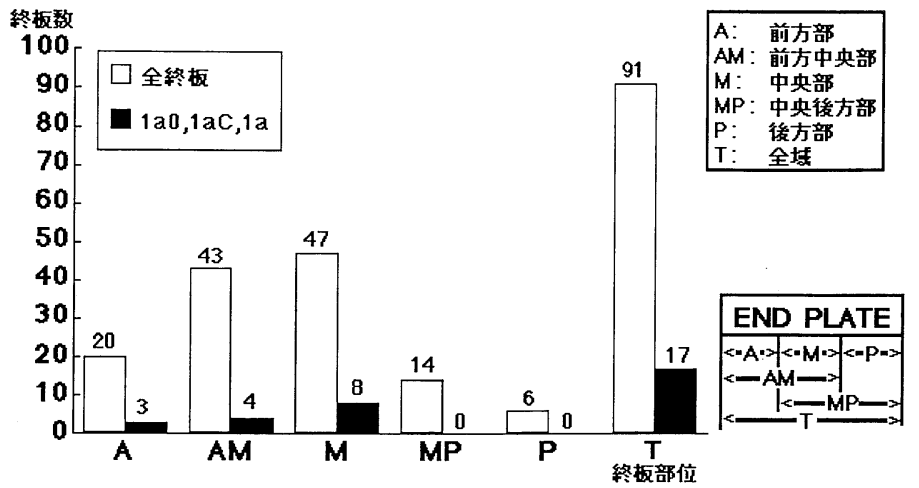

図 8 PDS 低下の部位別頻度

下を $4 \%$ に, 1 度以上の信号低下を 140 髄核 $28 \%$ に認 めた(図 5 ). 、レベル別では下位椎間程信号低下が増加, $\mathrm{L}_{1 / 2}$ で $2 \%, \mathrm{~L}_{2 / 3}$ で $4 \%, \mathrm{~L}_{3 / 4}$ で $13 \%, \mathrm{~L}_{4 / 5}$ で $56 \%, \mathrm{~L}_{5 / 6}$ で $84 \%$ に認めた。低下を前方型後方型全域型の部位別 にみると明らかに前半部の低下が多く(図 6)，母核が 正常で前方部のみ信号低下を認める $1 \mathrm{aO}, 1 \mathrm{aC}$ の存 在，また後方型が少ないことを考えると䯣核の信号低 下は前半部より始まりしだいに後方へ進展することが 示唆される。

PDS の信号強度別頻度は正常すなわち 0 度 $56 \%$, I 度 $25 \%$, II度 $17 \%$, III度 $2 \%$ でり, 低下例のレ ベル別では下位椎間程低下，その傾向はNS と酷似し ており両者は有意水準 $5 \%$ で 0.79 と高い相関性を認 めた（図 7 ).

PDS の低下部位を前方部・前方中央部・中央部・中 央後方部・後方部・全域に分類すると, 222 終板中 91 終板は全域にわたるものの, 110 終板は中央よりやや 前半部に偏在している(図 8)。これを椎間板変性の初 期と考えられる $1 \mathrm{aO}, 1 \mathrm{aC}, 1 \mathrm{a}$ の 32 終板でみると さらに明瞭となる。これらのことより初期の終板障害 は主として前半部より進展して行くものと考えられ る.

さらに NS 低下例 158 髄核中 152 終板に PDS の低 下を認めること（PDS 低下を認めないのは 6 終板の み), 正常髄核 342 髄核における PDS 低下は 70 終板 と少ないこと, PDS 低下 222 終板の中に NS 低下を 152 髄核に認めること（PDS 低下を認めても70髄核 は正常), PDS 正常で NS 低下は 278 椎間板中 6 髄核 のみであること等を考えるとその大半は終板が髄核よ
りも早期に信号低下をきたしてくつものと考えられ る.

考案

椎間板の水分に関する研究は Püschel ら ${ }^{17}$ に始ま り, Keyes ${ }^{9}$ が加令的にその含水度が低下することを報 告, 本邦では有馬の研究2)が有名であり, 加令的な水分 含有量とともに地理的水分含有量についても報告して いる，この含水性·水化機構に関しては, $\mathrm{Inman}^{7}$ の終 板を半透膜とする浸透圧説の他に Hendry ら ら $^{5}$ 髄核 の吸水性すなわち膨潤説を発表している。椎間板の水 分はほとんどが自由水であり,結合水は極めて少ない。 又 Franklini) は脂肪成分は約 $1 \%$ とており，MRで は高分子中のプロトン情報はえられない(16)ことより， その signal は自由水から得られるものである.さらに 自由水の保持には髄核のプロテオグリカンの吸水性・ 膨潤性が深く関与しておう， $\mathrm{T}_{2}$ 画像における信号低下 はプロテオカンの膨潤性の低下すなわち椎間板の変性 そのものを表現している. 今回の結果は髄核より終板 隣接椎体がより早く信号低下を起こす傾向にあるこ と，成長期における椎間板の信号低下は前半部より後 方へ進展していく傾向にあることを示唆するものであ る. 有馬 ${ }^{2)}$ は椎間板の含水量を部位別・年代別に検討, 10 才代では他の年代に比べて前方線維輪の方が髄核 よりもその含水量の低下が大きいことを報告してい る. Modic ${ }^{12)}$ は MRI $T_{1} T_{2}$ 画像にて信号低下した終板 を組織学的に肥厚した bony trabecula と報告, bone sclerosis と表現している.この sclerosis を含む何ら かの endplate faiure が diffusion や inbibition を障 
害，䯣核の二次的変性を起こすものと考えられる。 Ogata $^{10)}$ は Hydrogen Washout 法にて椎間板の主た る栄養代謝経路は経終板経路であり, bone-disc interface としての endplate 内の vascular budsの障害が 重要な役割を果たしているとしている。また石川や成 尾らはその組織学的検討により変性は終板に強く, 次 いで線維輪髄核の順であり，髄核の変性は終板軟骨の 障害が原因であると報告している，Roos ら ${ }^{18)}$ も MRI による終板軟骨と䯣核の信号強度を比較しており，終 板の focal な組織学的変化が䯣核の組織学的変化に先 行するものといえる．我々の MRIによる検討の結果 も同様の傾向にあり,これらを支持するものといえる. 日常の成人へルニア手術症例では, 椎間板後方部に変 性の強い例を多く経験するが，これは加令とともに変 性椎間板後方部にさらにメカニカルストレスが加重さ れ後方部変性を促進するものと考えられ，これがさら には後方線維輪に破綻をきたし脱出型へルニアへと進 行するものと考えられる.今後同一症例の経年的検討 が必要と思われる。

\section{ま と め}

1. 成長期 500 椎間板について $\mathrm{MRIT}_{2}$ 画像における 椎体終板前障害と髄核変性の関連について検討し た。

2. 終板前椎体の信号低下と髄核の信号低下との間に は高い相関が認められた。

3 ，髄核より終板前椎体の信号低下がより早期にきた すことが考えられ，髄核変性に先だって椎体障害に 引きつづき終板障害 endplate failure が起こること が示唆された。

4 , 弱年者の変性初期においては, 椎間板の信号低下 は前半部より始まり, 後方へ進行, 全体に拡大する 例が多かった。

\section{文献}

1) Aguila L. A. Oiraino D W, Mosic M T, et al ; Intranuclear Cleft of the Intervertebral Disk. Magnetic Resonance Imaging, Radiology 155 : 155 158, 1985

2）有馬 享：椎間板の水分に関する研究. 日整会誌 44 : $571 \sim 587,1970$

3) Eckert C, Decker A ; Pathological Studies of
Intervertebral Discs. J. Bone \& Joint Surg. 29 : 447 $\sim 454,1947$

4) Ftanklin L ; Lipid Content of the intervertebral Disc. Clin. Chem. $12 ; 253 \sim 257,1966$

5) Hendry N G C ; The Hydration of the Nucleus Pulposuss and its Relation to Intervertebral Disc Derangement. J. Bone \& Joint Surg. 40-B : 132 144

6）平田晴夫，服部 奨；椎間板組織の胎生期および生 後の加令的変化のついて. 日整会誌 $47: 298,1973$

7) Inman $\mathrm{V} \mathrm{T}$, Sanunfers $\mathrm{C} \mathrm{M}$; Anatomicophysiological Aspects of Injuries to the Intervertebral Disc. J Bone \& Joint Surg. 29 : 461 474, 1947

8）石川正士; 腰部椎間板へルニアの研究一特にその病 理学検討. 千葉医学誌 $38: 1 \sim 27,1948$

9) Keyes D C, compere E L ; The normal and pathological physiology of the Nucleus Pulposus of the Intervertebral Disc. J. Bone \& Joint Surg. 14 : 897 〜937, 1932

10) Kousuke Ogata, Whileside L A ; Nuturition Pathways of the Intervertebral Disc. an experimental study using hydrogen washout technique. Spine. 6 : 211 216, 1981

11) Maravilla K R, Chohen W A ; MRI atlas of the spine. Degenerative disc disease. Dunitz London 197 $\sim 219,1991$

12) Modic M T, Masaryk T J, Ross J S, et al ; Degenerative Disc Disease. Radiology 168 : 177 186, 1988

13) Modic M T, Steinberg P M, Ross J S et al ; Degenerative disc disease : asse-ssment of changes in vertebral body marrow with MR imaging. Radiology $166: 193 \sim 199,1988$

14）成尾正图, 小柳英一, 本田五男; 腰部椎間板症におけ る組織学的, 組織化学的検討. 西日本整災誌 $22 ： 458$ $\sim 462,1973$

15）岡田祐司, 井形高明, 村瀬正昭ほか; 成長期腰椎椎体 終板障害の MRI による検討。日整会誌 66 : S509, 1992

16）逢坂 昭：NMR医学 丸善 東京 159 ～169, 1984

17) Puschel J : Der Wassergehalt normaler und degenerirter Zwischenwirbelscheiben. Beitr. Path. Anat. $84: 123 \sim 128,1930$

18) Roos A, Kressel H, Spritzer $C$ et al ; MR Imaging of Marrow Changes adjacent to End Plates in Degenertive Lumbar Disc Disease. AJR 149 : 531 〜534, 1987

19）辻 博三, 井形高明, 村瀬正昭ほか ; 成長期腰椎障害 としての椎間板へルニアおよび後方型終板障害 $-\mathrm{MRI}$ による検討一。日脊会誌 $3: 133,1992$ 